\title{
HUKUM MODERN DAN PROSES PENAKLUKAN
}

\author{
Oleh:
}

\section{Faisal}

\begin{abstract}
Scientific of modern law is strongly influenced by the emergence of the paradigm of positivism. Modern law which in various ways or road, then spread to various parts of the world, is a type of law reached the peak of its development in the 19th century in Europe. The influence of modern law can make local laws with all their local wisdom becomes alienated in your own home. This is done by a process of conquest.
\end{abstract}

Keywords: Modern law, Positivism, Scientific.

\section{A. PENDAHULUAN}

Hukum sebagaimana diterima dan dijalankan di negara-negara dunia dewasa ini, pada umumnya termasuk ke dalam kategori hukum yang modern. Kelahiran hukum modern bagaikan tiba-tiba menciptakan suatu kultur kehidupan yang baru di dunia ini. Hukum modern mengantarkan kehidupan dan peradaban manusia kepada suatu momentum terjadinya pencabangan.
Sejak saat itu kehidupan hukum dihadapkan kepada suatu persimpangan jalan, yang satu pada aras jalan keadilan, sedangkan yang lain memusatkan perhatian pada pengoperasian hukum modern secara lebih pasti dan akuratif. Hal tersebut menimbulkan situasi yang cukup rumit, karena keduanya hampir bertolak satu sama lain. 
Sejak munculnya hukum modern, seluruh tatanan sosial yang ada mengalami perubahan luar biasa. Kemunculan hukum modern tidak terlepas dari munculnya negara modern. ${ }^{1}$ Proses pembentukan negara modern merupakan bagian dari sejarah "deferensiasi" kelembagaan, yang menunjukkan bagaimana fungsi-fungsi utama dalam masyarakat itu tampak ke depan sepanjang berlangsungnya proses tersebut. Dari situ akan terlihat terjadinya pengorganisasian masyarakat yang semakin meningkat, melalui berbagai elaborasi dari fungsi-fungsi tersebut. ${ }^{2}$

Bagi ilmu hukum, hal ini merupakan sebuah puncak perkembangan yang ujungnya berakhir pada dogmatisme hukum, liberalisme, kapitalisme, formalisme dan kodifikasi. ${ }^{3}$

Munculnya sistem hukum modern menurut Satjipto Rahardjo:

Merupakan respon terhadap sistem produksi ekonomi baru (kapitalis), karena sistem yang lama sudah

${ }^{1}$ Otje Salman \& Anthon F. Susanto, 2008, Teori Hukum "Mengingat, Mengumpulkan, dan Membuka Kembali, ctk.Keempat, Bandung, Citra Aditya Bakti, hlm. 146.

2 Dalam penjelasan Gianfranco Poggi, ia membagi proses pembentukan tersebut ke dalam tahap feodalisme, standestaat, absolutisme, civil society, dan contitusional state. Satjipto Rahardjo, 2000, Ilmu Hukum, Bandung, Citra Aditya Bakti, hlm 215. hlm 147. tidak bisa lagi melayani perkembangan-perkembangan dari dampak bekerjanya sistem ekonomi kapitalis tersebut. Dengan demikian tidak dapat disangkal bahwa sistem hukum modern merupakan konstruksi yang berasal dari tatanan sosial masyarakat Eropa Barat semasa berkembangnya kapitalisme pada abad ke-19.

\section{B. PEMBAHASAN}

Pertemuan antara hukum modern dan hukum setempat (misalnya hukum adat $)^{5}$ yang telah ada lebih dahulu selama puluhan tahun bahkan ratusan tahun, menimbulkan hal yang berseberangan antar keduanya.

Dikatakan demikian, oleh karena di situ tidak hanya terjadi pertemuan antara dua bentuk atau format hukum yang berbeda, melainkan juga pertemuan antara

${ }^{4}$ FX. Adji Samekto, 2008, Justice Not For All "Kritik Terhadap Hukum Modern dalam Perspektif studi Hukum Kritis”, ctk.Pertama, Yogyakarta, Genta Press, hlm. 40.

${ }^{5}$ Menurut pemahamannya, hukum adat pada dasarnya diturunkan dari rasa kepatautan, yang karenanya masyarakat merasa wajib untuk menaatinya. Sebagaimana yang dijelaskan oleh Snouck Hurgronje, hukum adat mempunyai makna sebagai keseluruhan hukum dari masyarakat pendahulu maupun kebiasaan yang disusun oleh para tetua, yang berbeda dari apa yang disusun oleh generasi kemudian. Sedangkan Moh. Koesnoe tampaknya ingin mendefinisakan hukum adat atas dasar cakupan artinya yang sangat luas dalam kehidupan masyarakat. Dalam pengertian beliau, hukum adat esensinya adalah keseluruhan ajaran nilai dan implementasinya yang mengatur cara hidup masyarakat. Ratno Lukito, 2008, Tradisi Hukum Indonesia, ctk.Pertama, Yogyakarta,Teras, hlm. 6-7. 
dua cara hidup atau kultur yang sangat kontras. Inilah yang menyebabkan pertemuan itu seringkali terlihat sangat dramatis.

Hukum modern yang melalui berbagai macam cara atau jalan, kemudian menyebar ke berbagai penjuru dunia, adalah suatu tipe hukum yang mencapai puncak perkembangannya pada abad ke-19 di Eropa. Sejak semua itu berlangsung di Eropa daratan, maka perkembangan hukum juga harus berbagi (sharing) dengan perkembangan sosial-budaya yang sama. Artinya, perkembangan hukum itu tidak terlepas dari perkembangan kultur di bagian dunia tersebut. ${ }^{6}$

Akan tetapi dalam kesempatan yang sama, tidak jarang kita melihat pengaruh dari hukum modern dapat membuat hukum setempat dengan segala kearifan lokalnya menjadi terasing di rumahnya sendiri. Hal tersebut dilakukan dengan sebuah proses penaklukan.

Salah contoh yang terjadi di tanah air, ketidakberdayaan sekelompok "suku anak dalam" yang menolak bagian dari

\footnotetext{
${ }^{6}$ Hukum tersebut memulai sejarahnya sejak abad-abad ke-7 dan ke-8, yaitu masa feodalisme, dan terus tumbuh serta berkembang melewati abadabad ke-12, 15, 17 dan mencapai puncaknya pada abad ke-19, dengan rule of law dan negara konstitusionalitas. Satjipto Rahardjo, 2007, Biarkan Hukum Mengalir, ctk.Pertama, Jakarta, Kompas, hlm. 106.
}

warganya untuk tidak diadili menurut hukum positif (hukum negara), mereka melakukan ritual adat di depan kantor Pengadilan Sarolangun di Jambi, hal ini merupakan cermin marginalisasi terhadap hukum adat setempat. Apa yang terjadi terhadap suku anak dalam di SarolangunJambi adalah contoh kecil saja dari apa yang terjadi di banyak bagian belahan dunia.

Fakta ini menunjukkan, bahwa tidak semua negara dan bangsa di dunia memiliki kosmologi seperti bangsa-bangsa di Eropa yang nota-bene sebagai pengekspor hukum modern. Bangsa-bangsa di kawasan Asia Timur, di mana Indonesia berada, tentunya memiliki kosmologi yang berbeda. Nilai-nilai dan tradisi mereka lebih bersifat kontekstual daripada individual. Dengan demikian hukum modern yang sangat Eropa-sentris berkorespondensi dengan dinamika kultur di bagian dunia tersebut, sehingga sistem hukumnya juga memiliki muatan kultur Eropa yang sangat kuat. ${ }^{7}$

${ }^{7}$ Untuk menyebut contoh yang lain, yaitu pengaruh hukum modern di Micronesia. Hukum Micronesia adalah sebuah tranplantasi, yaitu hukum Amerika Serikat yang diterapkan di negara kepulauan tersebut. Ternyata pada waktu itu masyarakat Micronesia beranggapan bahwa hukum modern lebih banyak menimbulkan persoalan daripada menyelesaikan masalah. Satjipto Rahrdjo, 2008, Negara Hukum Yang Membahagiakan 
Watak liberal dari hukum modern, yaitu adanya spirit hegemoni yang tidak akan membiarkan adanya bentuk tatanan lain (hukum) kecuali yang dibuat dan dikeluarkan oleh negara. Karena hukum modern sangat identik dengan hukum negara. Dengan begitu hukum harus dibuat oleh badan khusus, dirumuskan secara tertulis, dan diumumkan kepada publik. Akibatnya yang tidak memenuhi kualifikasi tersebut tidak bisa disebut sebagai hukum.

Perubahan tersebut sangat revolusioner karena secara radikal telah menghilangkan tatanan yang lama digantikan dengan yang baru dan berbeda sama sekali. Sejak saat itu, hukum tidak lagi muncul dari dalam proses interaksi antara anggota masyarakat itu sendiri, melainkan merupakan sesuatu yang artifisial karena dibuat secara sengaja oleh badan tertentu yang diberi wewenang khusus oleh negara untuk itu.

Sejak saat itulah negara
menghendaki dalam mengoperasikan
hukum dengan logika yang rasional.
Dengan begitu hukum tidak lagi semata-
mata tempat untuk mencari keadilan,
melainkan juga menerapkan undang-

Rakyatnya, ctk.Pertama, Yogyakarta, Genta Press, hlm. 39-40. undang berdasarkan prinsip kepastian hukum.

Disinilah hukum modern berada di persimpangan, sebab antara keadilan dan hukum yang diterapkan terdapat perbedaan yang sangat besar. Wilayah keadilan tidak persis sama dengan wilayah hukum positif. Keadaan yang menunjukkan adanya jarak persimpangan tersebut, juga memunculkan pengertian-pengertian seperti keadilan prosedural di satu pihak dan keadilan subtantif di pihak lain.

Dapat dikatakan bahwa, saintifikasi hukum modern sangat di pengaruhi oleh kemunculan paradigma positivisme di dalam ilmu pengetahuan modern. Watak liberal hukum modern yang mengajarkan untuk menerapkan hukum secara rasional. ${ }^{8}$ Rasionalitas ini ditandai oleh sifat peraturan hukum yang prosedural. Sebagaimana Max Weber menyatakan:

Bahwa prosedur penyelenggaraan hukum yang semakin berteknik rasional dan menggunakan metode deduksi yang semakin ketat, merupakan tahapan dalam perkembangan hukum sehingga hukum dapat disebut sebagai hukum modern. ${ }^{9}$

\footnotetext{
${ }^{8}$ FX. Adji Samekto, Op., Cit, hlm. 33.

${ }^{9}$ Ibid.
} 


\section{PENUTUP}

Jadi David M. Trubek hendak menyatakan bahwa pendapat Weber menunjukkan bahwa hanya hukum yang rasional dan modern atau ketentuan yang formal rasional dan logis, yang dapat digunakan untuk kepentingan-kepentingan secara pasti. Dalam hal ini, legalisme akan mendorong perkembangan kapitalisme melalui penciptaan kondisi yang stabil dan dapat diprediksikan. ${ }^{10}$

Tidak heran kemudian paradigma postivisme menjadi bagian dari hadirnya hukum modern tersebut. Sehingga hukum modern beserta implikasinya dapat menimbulkan kekakuan dalam pencarian kebenaran dan keadilan, akan menjadi tidak tercapai karena terhalang oleh "tembok-tembok" prosedural. ${ }^{11}$

Dapat dikatakan, bahwa tidak mudah untuk mewujudkan keadilan subtantif karena terkadang kita dihadapkan oleh prosedur hukum yang sangat ketat dalam memenuhi legalitas sistem hukum modern. Hal ini disebabkan paradigma positivisme telah menyebarkan pengaruhnya dan bermetamorfosa menjadi postivisme hukum.

\section{DAFTAR PUSTAKA}

Lukito, Ratno, 2008, Tradisi Hukum Indonesia, ctk.Pertama, Yogyakarta,Teras.

Rahardjo, Satjipto, 2000, Ilmu Hukum, Bandung, Citra Aditya Bakti. , 2007, Biarkan Hukum Mengalir, ctk.Pertama, Jakarta, Kompas.

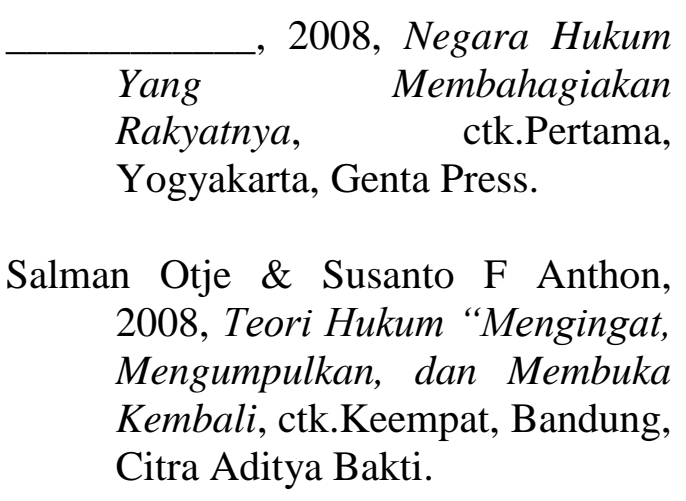

Samekto, Adji FX., 2008, Justice Not For All "Kritik Terhadap Hukum Modern dalam Perspektif studi Hukum Kritis", ctk.Pertama, Yogyakarta, Genta Press.

\footnotetext{
${ }^{10}$ Ibid.

${ }^{11}$ Ibid.
} 